\title{
GEOPHYSICAL SURVEYS OF A POTENTIALLY EXTENSIVE CAVE SYSTEM, GUADALUPE MOUNTAINS, NEW MEXICO, USA
}

\author{
Lewis Land ${ }^{1}$ and Alex Rinehart ${ }^{2}$
}

\begin{abstract}
Between 2012 and 2015 National Cave and Karst Research Institute (NCKRI) personnel conducted electrical resistivity and microgravity surveys over Manhole Cave, located on public land administered by the US Bureau of Land Management (BLM) in the Guadalupe Mountains of southeastern New Mexico. Manhole Cave is a relatively shallow pit cave, but it is thought by many cavers to be a second entrance to Lechuguilla Cave, the second deepest cave in the continental United States. Digging in Manhole Cave has been occurring sporadically for many years, following airflow through cemented breakdown. Results of resistivity surveys conducted over the cave show a high-resistivity anomaly southwest of the cave entrance, consistent with microgravity survey results that show a negative gravity anomaly in the same area. Combined geophysical results indicate that a substantial void is present in the subsurface a few tens of meters below ground level and extending to the south of the dig.
\end{abstract}

\section{Background}

The study area is located in the Delaware Basin region of southeastern New Mexico and west Texas. The Delaware Basin is one of the deepest sedimentary basins in North America, containing more than $7300 \mathrm{~m}$ of sedimentary rock that provide reservoirs for water, oil, and natural gas resources. A thinner sedimentary section overlaps the northern edge of the basin, extending for over $100 \mathrm{~km}$ beyond the basin margin across the Northwest Shelf (Fig. 1).

The Delaware Basin is rimmed by the Capitan Reef, a fossil reef of middle Permian (Guadalupian) age, that is exposed along the southeast escarpment of the Guadalupe Mountains. Here, it is the host rock for Carlsbad Cavern, the centerpiece of Carlsbad Caverns National Park (Fig. 2). Northeast of the Park, the reef plunges into the subsurface and passes beneath the city of Carlsbad, where it is a karstic aquifer that is the principal source of fresh water for that community (Hiss, 1975a). During middle Permian time, fine-grained sediments were deposited in shallow waters of the backreef area, behind the reef in a broad lagoon that extended across the Northwest Shelf. These sediments make up the carbonate and evaporite rocks of the backreef Artesia Group (Fig. 1; King, 1948; Hayes, 1964; Kelley, 1971; Land, 2003).

Caves, and other karst features in the Delaware Basin region, form in a semi-arid environment in a variety of geologic settings, in both carbonate and gypsum bedrock. Most caves in the Guadalupe Mountains are formed in limestones of the Capitan Reef Formation, or in dolomites of the backreef Artesia Group. For many years the prevailing theory of cave formation in the Guadalupe Mountains was that they were of epigenic origin, forming by carbonic acid dissolution near the water table (Bretz, 1949). However, since the 1980s, it is now widely accepted that caves in the Guadalupe Mountains are, for the most part, of hypogene origin, excavated by ascending artesian groundwater charged with sulfuric acid (Hill, 1987; Klimchouk, 2007).

Manhole Cave (known to many in the caving community as Big Manhole) is an approximately $20 \mathrm{~m}$ deep pit cave in the Guadalupe Mountains of southeastern New Mexico (Fig. 2), formed in backreef dolomites of the middle Permian Seven Rivers Formation (Fig. 1). The cave's entrance opens vertically beneath a dolomite ledge, and is protected by a steel gate to prevent unauthorized entry (Fig. 3). Its single chamber is approximately circular, and bells out from an entrance diameter of about one by three meters to a diameter averaging $27 \mathrm{~m}$ at the floor of the main chamber. The floor of the cave slopes upward from south to north, and the northern wall is within a meter of the ceiling (Lange, 1992). Most of the floor is covered with flowstone-cemented breakdown, which has been explored and excavated to a depth of about $30 \mathrm{~m}$ below the surface (Fig. 4).

Manhole Cave is located on federal land administered by the US Bureau of Land Management (BLM); its location places it less than $300 \mathrm{~m}$ north of the boundary with Carlsbad Caverns National Park. The cave is also located approximately $300 \mathrm{~m}$ (map distance) from the easternmost passages of Lechuguilla Cave, which lies within the boundaries of Carlsbad Caverns National Park (Figs. 2 and 5). Lechuguilla Cave is currently the second deepest cave in the continental United States (489 m; Gulden, 2016a) and, at $223 \mathrm{~km}$, the seventh longest cave in the world (Gulden, 2016b). Lechuguilla Cave is generally assumed to have formed by hypogenic processes involving ascending, sulfuric acid-enriched

${ }^{1}$ National Cave and Karst Research Institute, New Mexico Institute of Mining and Technology, 400-1 Cascades Ave., Carlsbad, New Mexico 88220, USA. Lewis.land@nmt.edu.

${ }^{2}$ New Mexico Bureau of Geology and Mineral Resources, New Mexico Institute of Mining and Technology, 801 Leroy PI., Socorro, New Mexico 87801, USA. Alex.rinehart@nmt.edu. 
$\mathbf{N}$

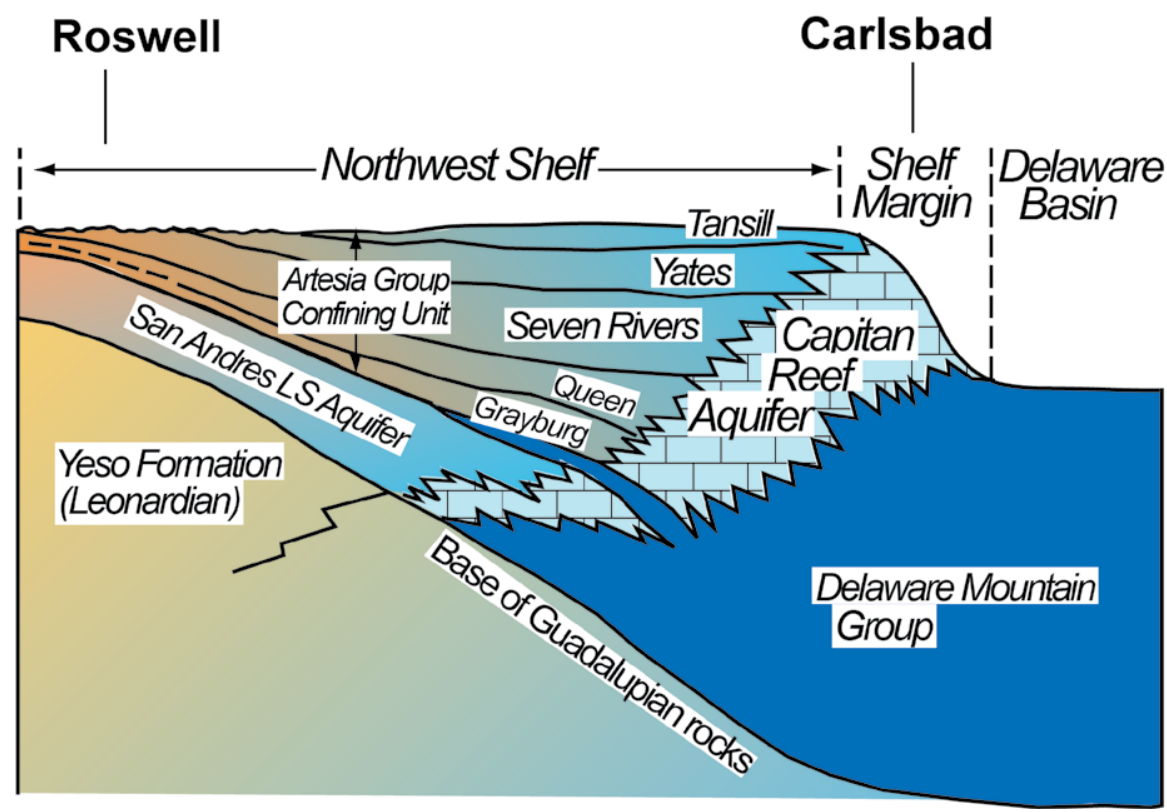

Figure 1. Regional stratigraphy of Guadalupian (middle Permian) rocks in southeastern New Mexico. Modified from Hiss (1975b). groundwater, derived from oil and gas accumulations in the Delaware Basin of southeastern New Mexico and west Texas (Hill, 1987; Palmer and Palmer, 2000). The cave contains a remarkable assemblage of rare speleothems and communities of chemolithoautotrophic bacteria, which are thought to have contributed to enlargement of the cave (Northup, et al., 2000). Access to Lechuguilla Cave is limited to scientific research and survey of its extent as approved by the National Park Service (NPS).

Strong airflow emerging from cracks in the flowstone-covered floor of Manhole Cave indicates that the cave probably extends beyond its mapped limits. This phenomenon, and Manhole's proximity to Lechuguilla Cave, has generated speculation that Manhole Cave may represent an entrance to one of the most distant points in Lechuguilla. Beginning in 1986, this airflow has motivated exploratory digging by caver volunteers beneath the south wall of the cave (Fig. 4).

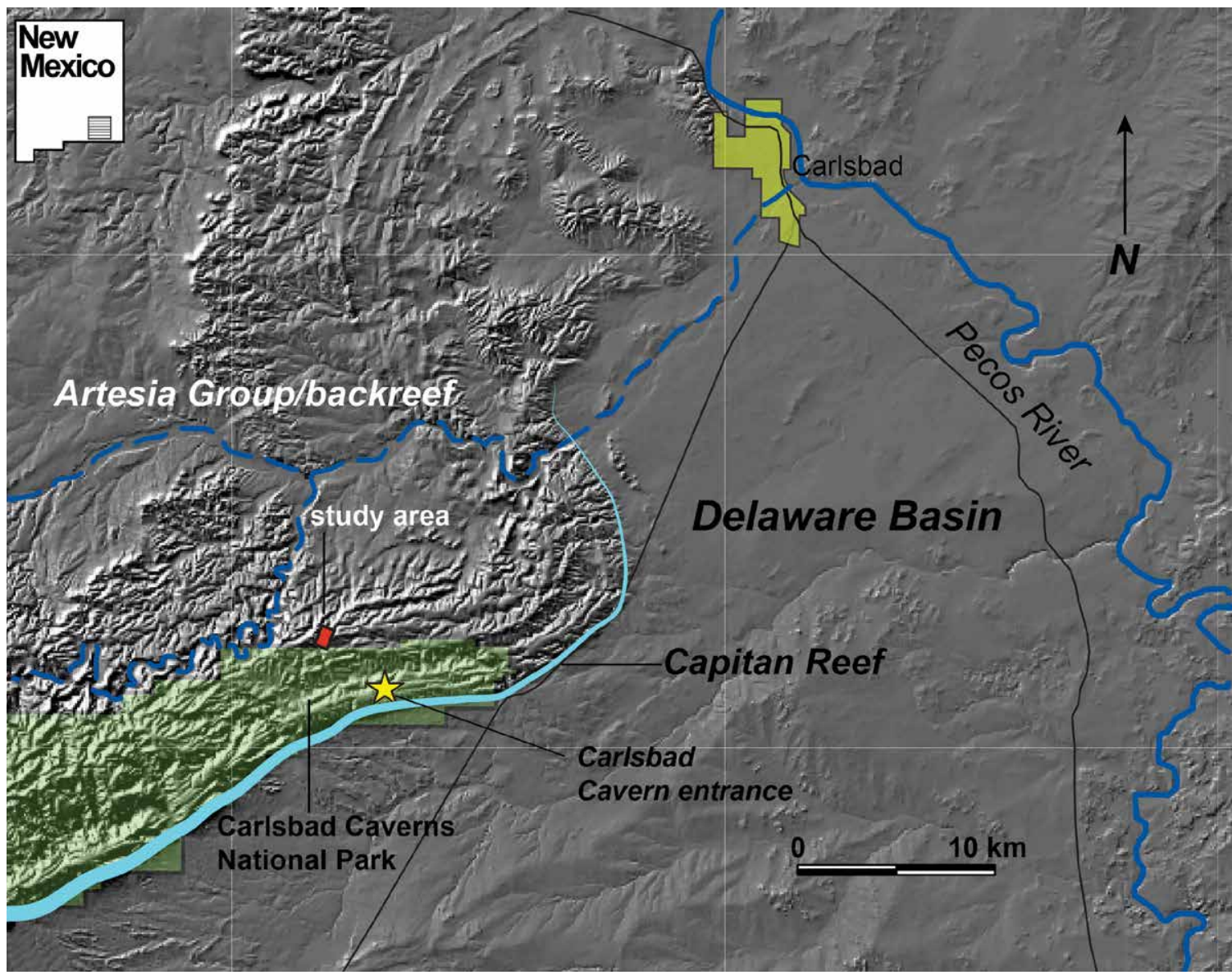

Figure 2. Map showing location of study area. Carlsbad Caverns National Park is shown by green shading. Capitan Reef outcrop is shown by blue shading along the Guadalupe Mountain front. 


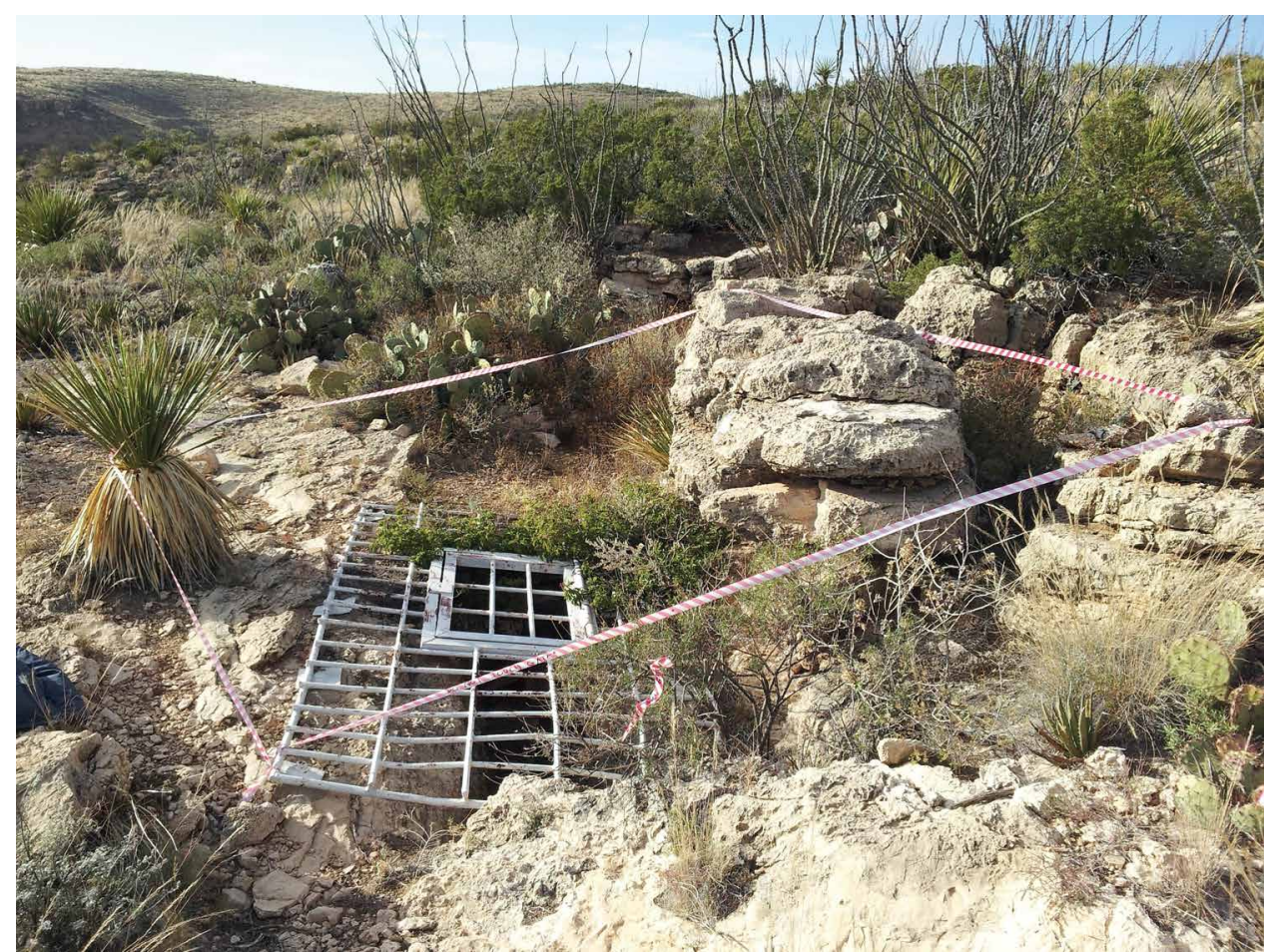

Figure 3. Manhole Cave entrance, formed in backreef carbonates of the Artesia Group/Seven Rivers Formation.

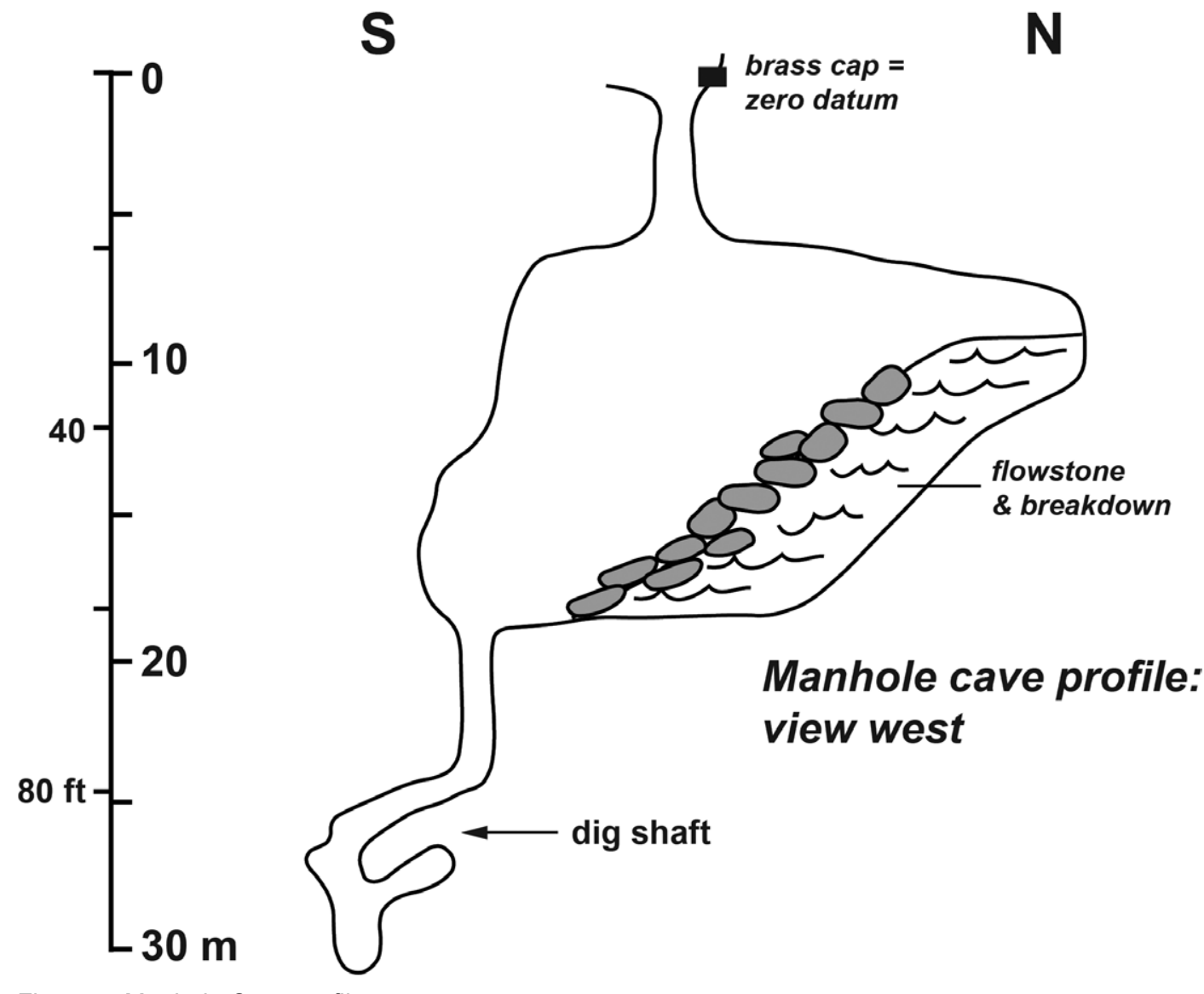

Figure 4. Manhole Cave profile.

\section{Previous Work}

In 1992, the Geophysics Group conducted a natural potential (NP) survey over Manhole Cave (Lange, 1992). The survey consisted of a grid of eight lines oriented north-south, with the medial lines passing directly over the mapped cave. Results of the survey show a large positive NP anomaly, south-southeast of the cave entrance. Lange (1992) interpreted this anomaly as indicating the presence of conduits or cave galleries that extended beyond the limits of the survey grid.

In 2004 and 2005, John McLean (2005) conducted 2D electrical resistivity surveys over Manhole Cave, using dipole-dipole arrays with 15 and 30 m electrode spacing. These surveys identified a large, high-resistivity anomaly, presumably caused by an airfilled cavity located about 30 to $60 \mathrm{~m}$ south of the Manhole Cave entrance at a depth of about $40 \mathrm{~m}$. One branch of the anomaly passes within $20 \mathrm{~m}$ of the cave. Several shallow, high-resistivity zones were also identified in the northeast and southwest parts of the survey area, which McLean suggested might represent small, independent caves or parts of a larger hypogenic cave system. The deep resistivity anomaly generally agrees with the NP anomalies identified by Lange (1992).

\section{Methods}

During the winter of 2012-2013, the National Cave and Karst Research Institute (NCK$\mathrm{RI}$ ), assisted by BLM personnel and volunteers, conducted six 2D resistivity surveys over and adjacent to the entrance to Manhole Cave 


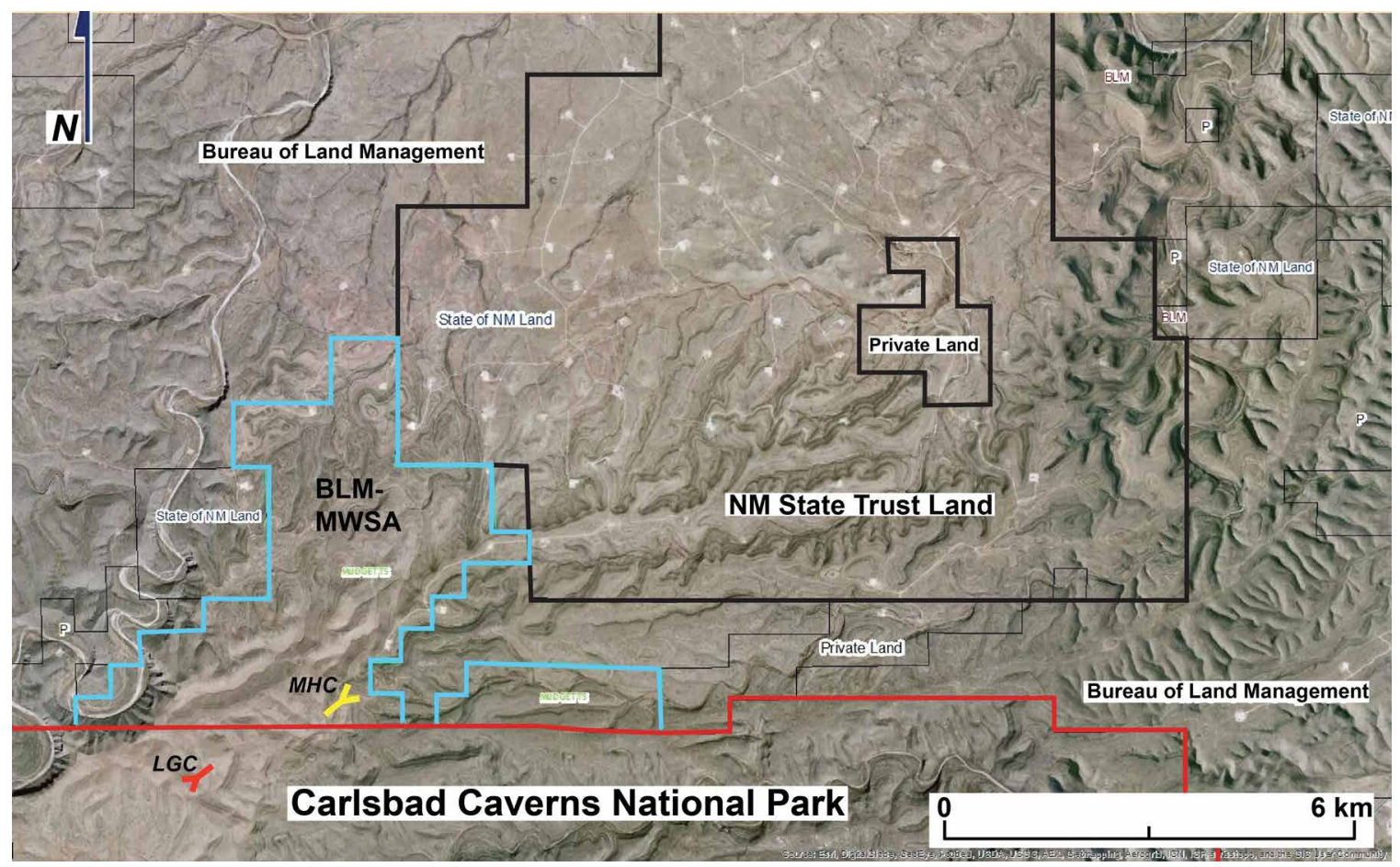

Figure 5. Detail of study area showing surrounding area land status. MWSA = Mudgetts Wilderness Study Area. $\mathrm{MHC}=$ Manhole Cave. LGC shows approximate location of Lechuguilla Cave entrance.

(Fig. 6), using 56 electrode dipole-dipole arrays at 6-m electrode spacing for higher resolution than previous resistivity studies. The survey lines were spaced $6 \mathrm{~m}$ apart, and data from these surveys were subsequently merged to develop a $2.5 \mathrm{D}$ resistivity model using Earthlmager $3 \mathrm{D}^{\mathrm{TM}}$ software.

Electrical resistivity (ER) surveys are a common and effective geophysical method for detection of subsurface voids. The basic operating principle for an ER survey involves generating a direct current between two metal electrodes implanted in the ground, while measuring the ground voltage between two other implanted electrodes. Given the current flow and voltage drop between the electrodes, differences in subsurface electrical resistivity can be determined and mapped. Modern resistivity surveys employ an array of multiple electrodes connected with electrical cable. Over the course of a survey, pairs of electrodes are activated by means of a switchbox and resistivity meter. The depth of investigation for a typical ER survey is approximately one-fifth the length of the array of cable.

Resistivity profiles illustrate vertical and lateral variations in subsurface resistivity. The presence of water, water-saturated soil, or bedrock will strongly affect the results of a resistivity survey. Air-filled caves or air-filled pore space in the vadose zone are easy to detect using the ER method, since air has near-infinite resistivity, in contrast with 10 to 15 orders of magnitude more conductive surrounding bedrock. Previous work (Land and Veni, 2012; Land, 2013) has shown that resistivity surveys are one of the most effective methods for identifying water-filled and air-filled voids due to their electrical contrast with surrounding bedrock.

During the spring of 2015, NCKRI personnel completed a microgravity survey in the vicinity of Manhole Cave, using a Scintrex CG-5 gravity meter with 5-microgal resolution. Because of the highly irregular topography (steep cliffs and deep canyons), detailed terrain corrections had to be applied to the gravity data, instead of the simpler Bouguer slab correction. Gaps in the survey grid (Fig. 7) reflect areas of near-vertical topographic relief, where it was not possible to deploy the gravity meter. High wind conditions introduced additional challenges in data acquisition, since wind-induced vibration required longer measurement times at each station to reduce standard deviations to acceptable levels. Deployment of portable wind barriers met with limited success.

Microgravity surveys are frequently conducted in conjunction with ER surveys. Gravity surveys estimate spatial variations in gravitational acceleration. These changes vary as a function of the density of the shallow subsurface according to Newton's Law (Blakely, 1995). Conceptually, these measurements are made by precisely measuring the force required to balance a mass on a spring. To understand changes in the shallow subsurface, variations in gravitational acceleration from six-to-eight significant figures are required. With advances in materials, mechanical design, and electronic controls, it is now routine to perform these measurements (Hinze et al., 2013).

The Scintrex CG-5 uses a weighted quartz spring, balanced by a capacitor with an internal feedback control system, for raw measurements. The CG-5 reports measurements with internal drift and tidal corrections. During a survey, a reference station is reoccupied periodically to account for additional instrument drift and tares ("jumps" in the gravity 


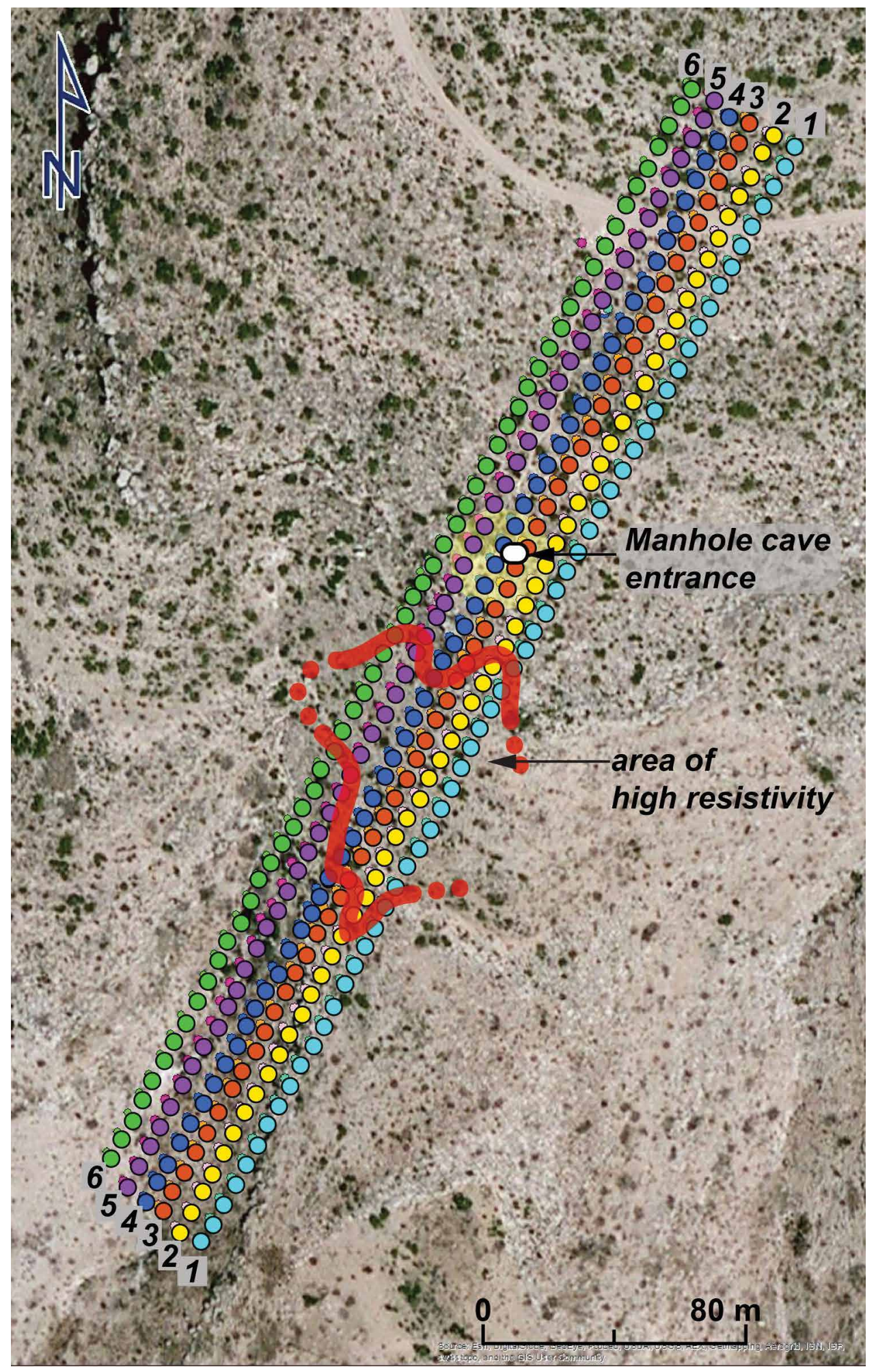

Figure 6. Electrical resistivity survey lines. Individual electrodes are shown by filled circles. White oval shows location of cave entrance. Line numbers reference ER profiles shown in Figure 7. Data sources, BLM, NCKRI, ESRI base maps. Cartography by Andrea K. Goodbar.

readings when the instrument is moved). With the electromechanical system, the internal corrections and the drift corrections with base station reoccupations, the maximum accuracy of the CG-5 is 5 microgal (approximately $10^{-8} \mathrm{~m} \mathrm{~s}^{-2}$ ).

To interpret the shallow subsurface structure, a number of corrections must be made to remove other, undesired effects. In many cases, the complete terrain-corrected Bouguer anomaly can be used to understand subsurface structures (Hinze et al., 2013). This anomaly remains after correcting for:

- the attraction of the reference geoid;

- the centrifugal acceleration as a function of latitude, reflecting changes in the shape of the geoid; 


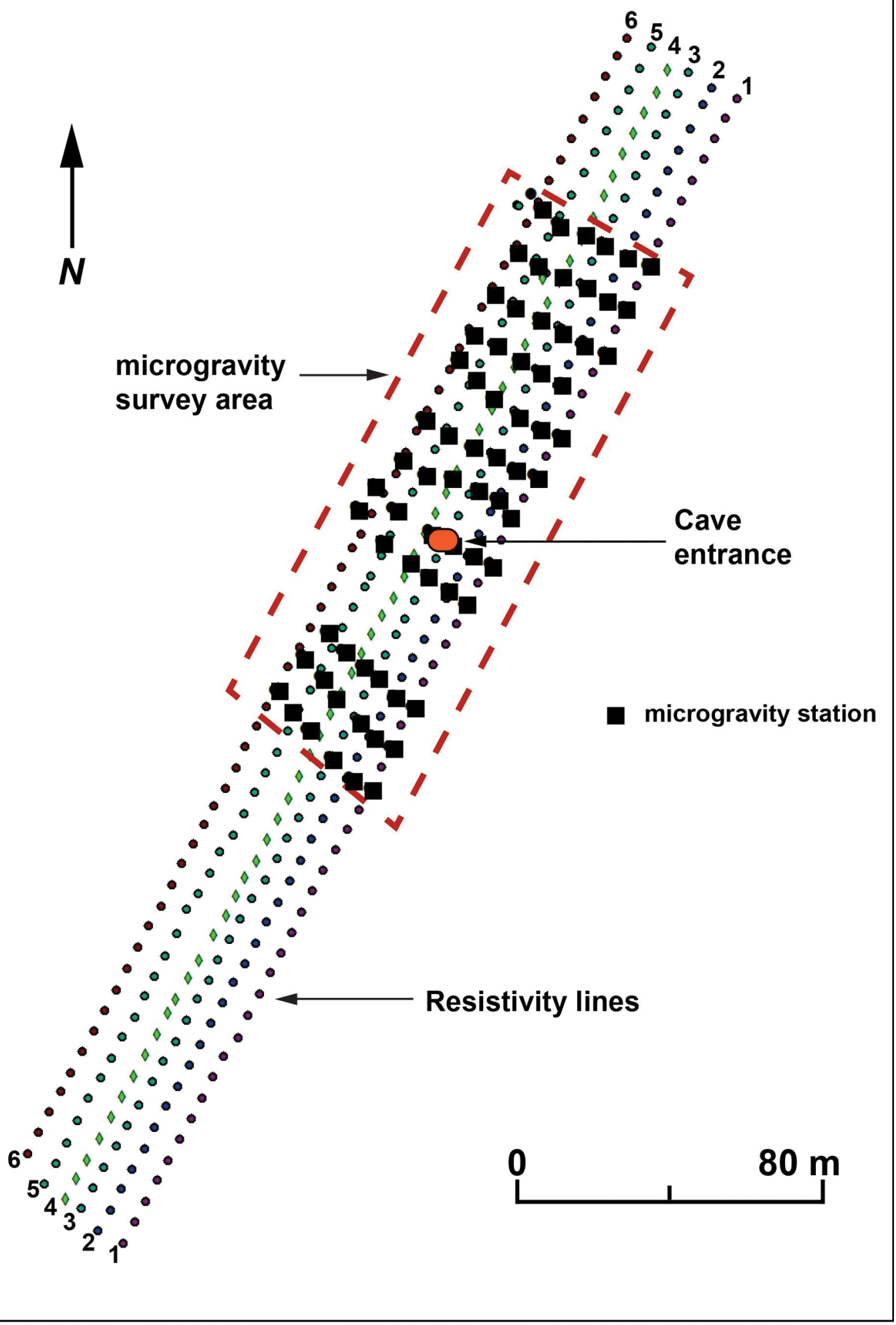

Figure 7. Comparison of resistivity survey lines and microgravity survey area. Orange oval shows location of cave entrance. Line numbers reference ER profiles shown in Figure 8. Black squares show locations of microgravity survey stations. NW-SE gravity survey lines are spaced approximately $12 \mathrm{~m}$ apart. Spacing of individual stations within each survey line is approximately $6 \mathrm{~m}$.

- the elevation of the measurement location above the geoid, or free air anomaly;

- earth tides;

- an estimate of the "normal" rock density above the geoid, or slab Bouguer anomaly; and

- effects from variations in terrain around the measurement point (Longman, 1959; Blakely, 1995).

With the CG-5, tidal corrections are made internally using the correction of Longman (1959). We made all of the other corrections, except for the terrain correction, based on site locations, using the simple formula in Blakely (1995). The terrain correction was computed numerically. We assumed a mean density of $2.6 \mathrm{~g} \mathrm{~cm}^{-3}$ for bedrock, and broke the 

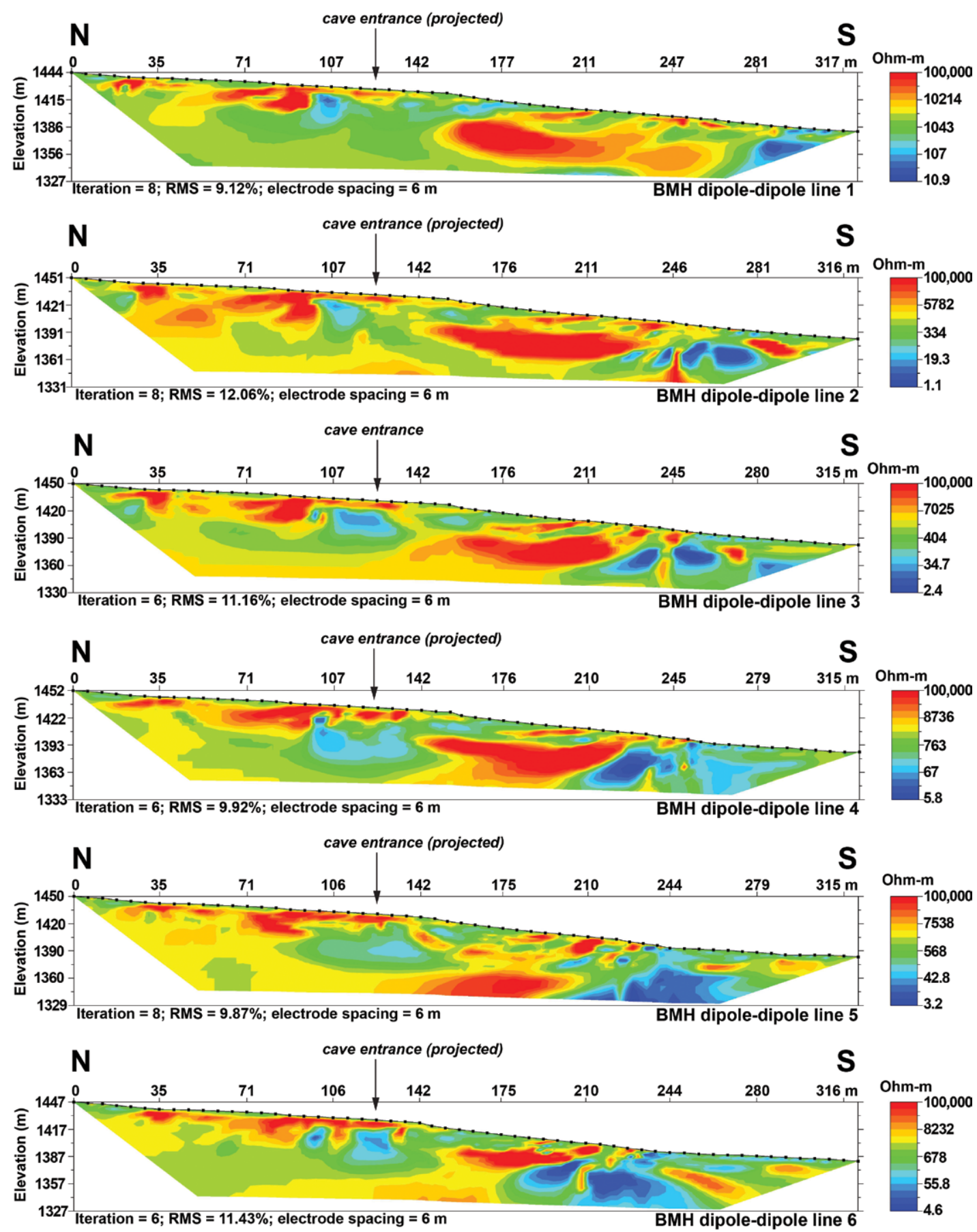

Figure 8f. Manhole Cave ER line 6. Cave entrance is about $17 \mathrm{~m}$ west of the survey line, and is projected onto the resistivity profile.

terrain into prisms using a $10 \mathrm{~m}$ digital elevation model (DEM). The vertical component of gravitational attraction from each prism is computed for every measurement point out to a radius of $150 \mathrm{~km}$ from the measurement point (Blakely, 1995), and then is removed from the measured gravity.

\section{Results and Discussion}

\section{Resistivity Surveys}

Terrain-corrected electrical resistivity surveys, conducted in the vicinity of Manhole Cave, achieved an investigation depth of approximately 60 to $90 \mathrm{~m}$ below ground level (bgl) (Figs. 8a-8f). The ER data are exceptionally noisy, probably the result of high contact resistance in the survey area, which is comprised largely of exposed dolomite bedrock with very thin and patchy soil cover. In many cases, a hammer drill was necessary to drill holes in the bedrock pavement for installation of electrodes. We achieved lower contact resistance in those cases by filling the holes with saltwater before 
insertion of the electrodes. We also used a data misfit histogram provided by Earthlmager ${ }^{\mathrm{TM}}$ software to remove data outliers and reduce the root mean square error during data processing.

ER line 3 passes less than one $\mathrm{m}$ east of the cave entrance (Fig. 8c). The entrance to the cave is projected onto the remaining five survey lines. Manhole Cave is shown by a shallow zone of high resistivity, at approximately $125 \mathrm{~m}$ on all six profiles. It is worth noting that Manhole Cave's relatively shallow, $20 \mathrm{~m}$, depth results in it not appearing prominently displayed because of the vertical scale of the ER profiles (e.g., line 3, Fig. 8c). Additional high-resistivity anomalies are visible at the northern end of all six lines, at depths ranging from approximately five to $40 \mathrm{~m}$. These anomalies may represent shallow caves or conduits independent of Manhole Cave. McLean (2005) identified similar shallow, resistivity anomalies north of the Manhole Cave entrance.

A distinctive feature of Lines 1 through 4 is a broad zone of high resistivity 35 to $120 \mathrm{~m}$ south of the cave entrance. This anomaly is visible on Line 1 at depths ranging from approximately 20 to $65 \mathrm{~m} \mathrm{bgl}$ (Fig. 8a). Resistivity values range from 10,000 to $100,000 \mathrm{ohm}-\mathrm{m}$, consistent with air-filled, void space in the subsurface. A similar high-resistivity anomaly is present on Line 2 (Fig. 8b) 15 to $55 \mathrm{~m} \mathrm{bgl}$, on Line 3 (Fig. 8c) at about 10 to $60 \mathrm{~m}$ bgl, and on Line 4 (Fig. 8d) at 10 to $60 \mathrm{~m} \mathrm{bgl}$.

The southern end of the large ER anomaly, visible on Lines 1 to 4, appears to curve upward toward the surface, although we encountered no evidence of cave entrances in that area during the ER surveys. Line 3 (Fig. 8c) also shows

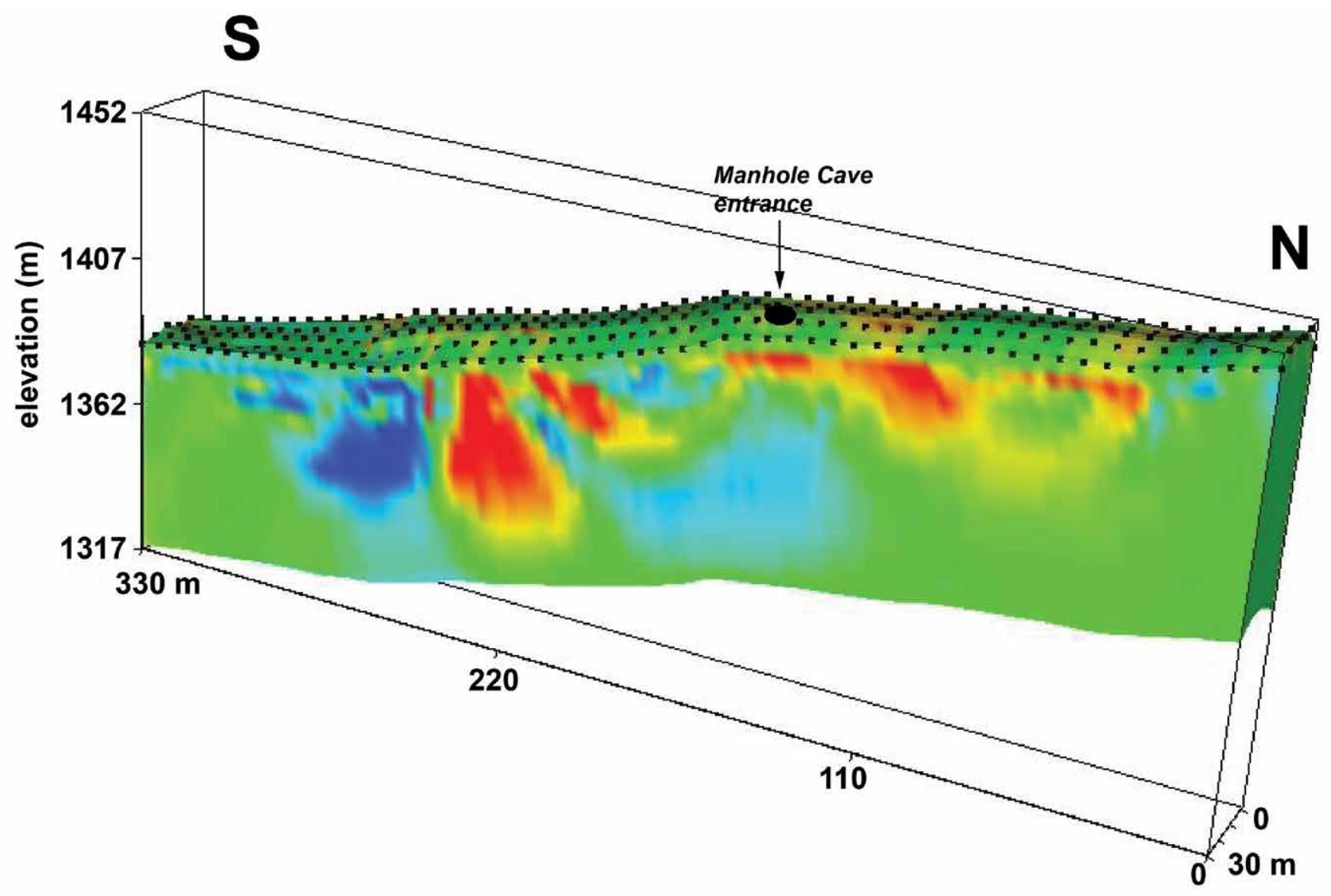

Combined 2.5D model; iteration $=8 ;$ RMS $=15.9 \%$

Resistivity (Ohm-m)

16.

144.

1277.

11300.

100000.

Figure 9. 2.5D model, view to west. 
a narrow zone of slightly lower resistivity (about 5000 to $7000 \mathrm{ohm}-\mathrm{m}$ ) that connects the Manhole Cave resistivity anomaly with the larger anomaly to the south at an angle of approximately $30^{\circ}$. If the resistivity anomaly to the south represents a larger cave, this feature may indicate the presence of a breakdown-choked passage linking the two caves. Smaller high-resistivity anomalies are visible at the south end of Lines 2 and 3, which may represent isolated cavities not connected to the larger void; or they may be the result of data-processing artifacts that are more common at the ends of resistivity profiles, where fewer data points are available for interpretation.

A high-resistivity feature is still present south of Manhole Cave on Line 5 (Fig. 8e) about 55 to $75 \mathrm{~m}$ bgl, overlain by several smaller and shallower anomalies. A southern anomaly is also present on Line 6 (Fig. 8f) at a significantly shallower depth, 10 to $30 \mathrm{~m}$ bgl, that may correlate with the shallow anomalies observed on Line 5 . These features may represent shallower corridors and/or galleries above the main void space south of Manhole Cave. If this interpretation is correct, it suggests that the southern cave system may turn to the southeast, beyond the limits of the ER surveys (Fig. 6).

Earthlmager $3 \mathrm{D}^{\mathrm{TM}}$ software was used to merge the six $2 \mathrm{D}$ resistivity lines to create a $2.5 \mathrm{D}$ model of the survey area (Fig. 9). The software was then used to generate slices at depth increments of five meters through the 2.5D model (Figs. 10a-10g). The slices terminate at varying distances from the northern end of the model because of steep topography in the survey area, causing the horizontal slices to extend into what would be open air above a broad arroyo.

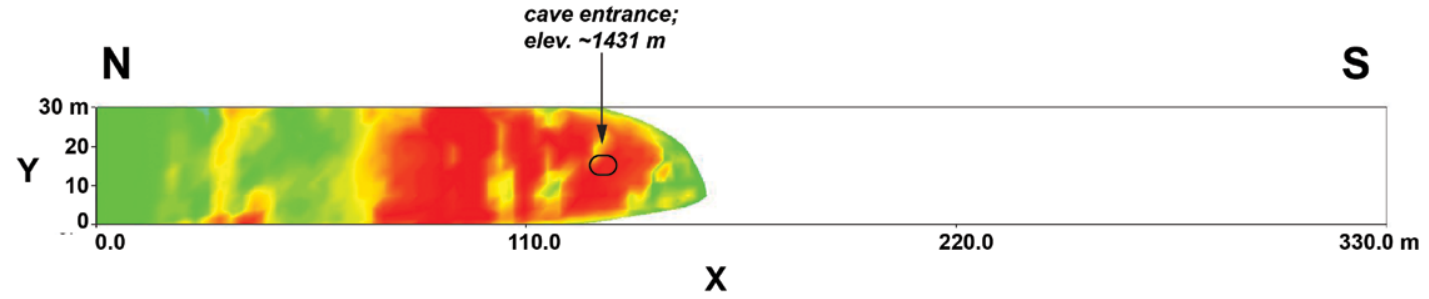

Z slice: $1427 \mathrm{~m}$

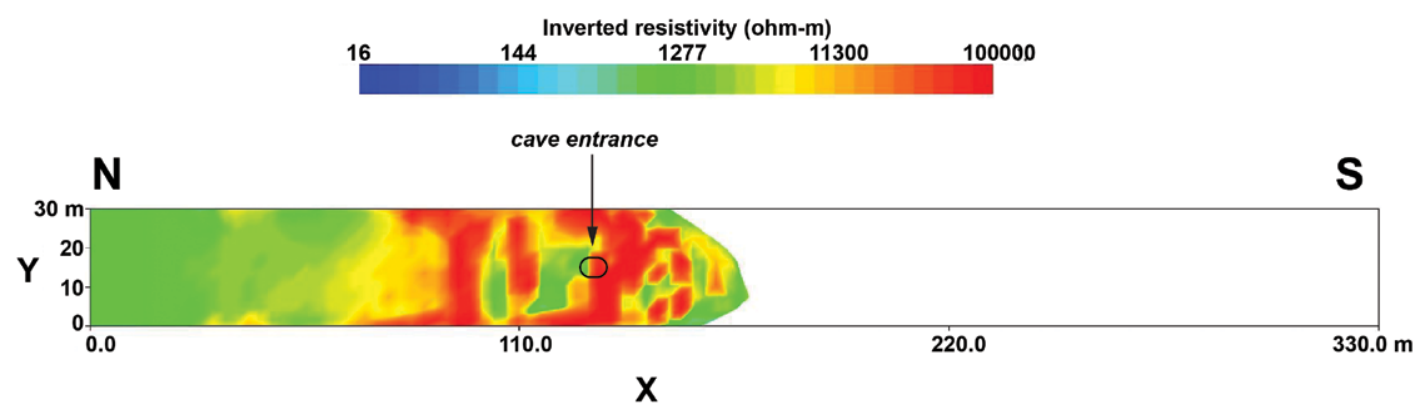

Z slice: $1422 \mathrm{~m}$

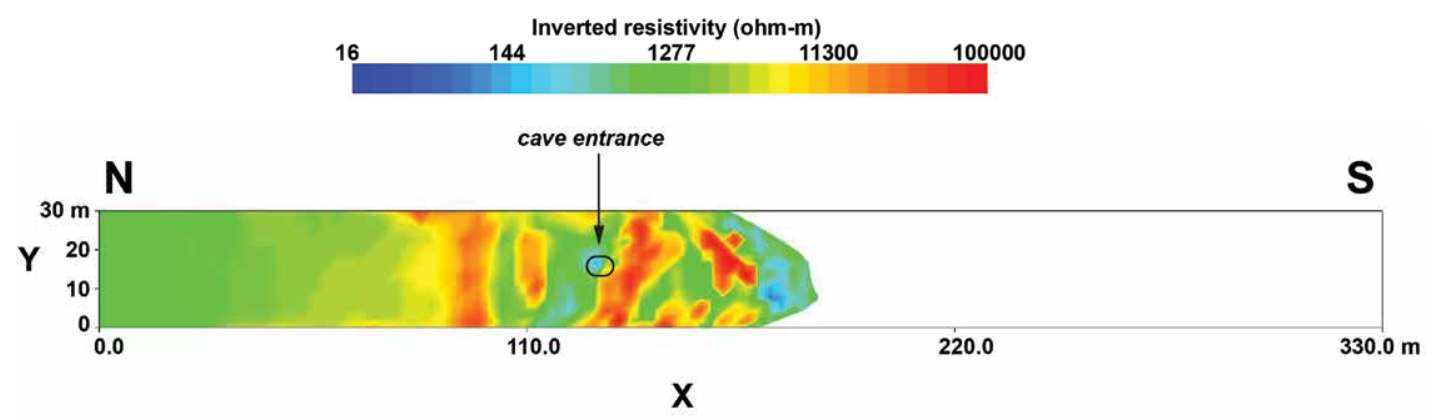

Figure 10a. 1427 m layer, approximately four $\mathrm{m}$ bgl at the cave entrance. Steep terrain in the survey area causes this layer (and subsequent ones) to terminate to the south, where the horizontal slice projects into open air above an arroyo. High resistivity in this slice indicates the presence of air-filled void space in Manhole Cave, and additional shallow zones of high resistivity north of the cave entrance.

Figure 10b. $1422 \mathrm{~m}$ layer. High resistivity results from air-filled void space near the center of Manhole Cave.

Figure 10c. $1417 \mathrm{~m}$ layer, just above the cave floor.

\section{Z slice: 1417 m}

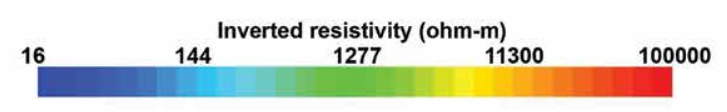




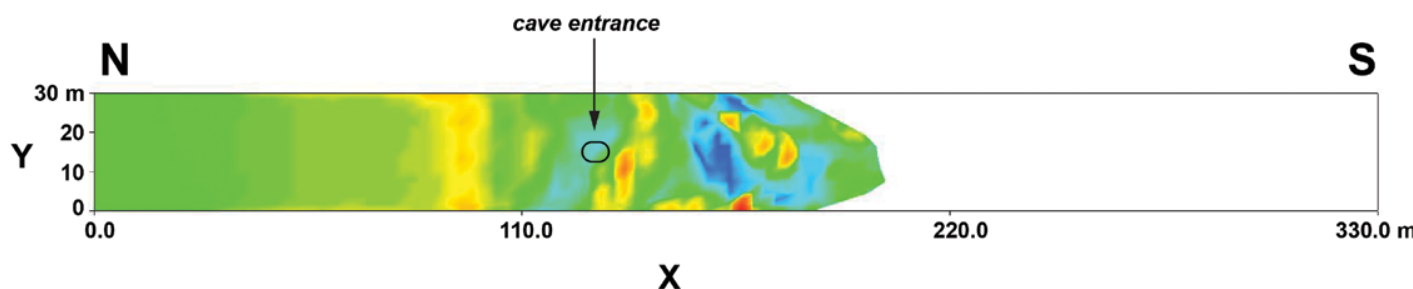

\section{Z slice: $1412 \mathrm{~m}$}

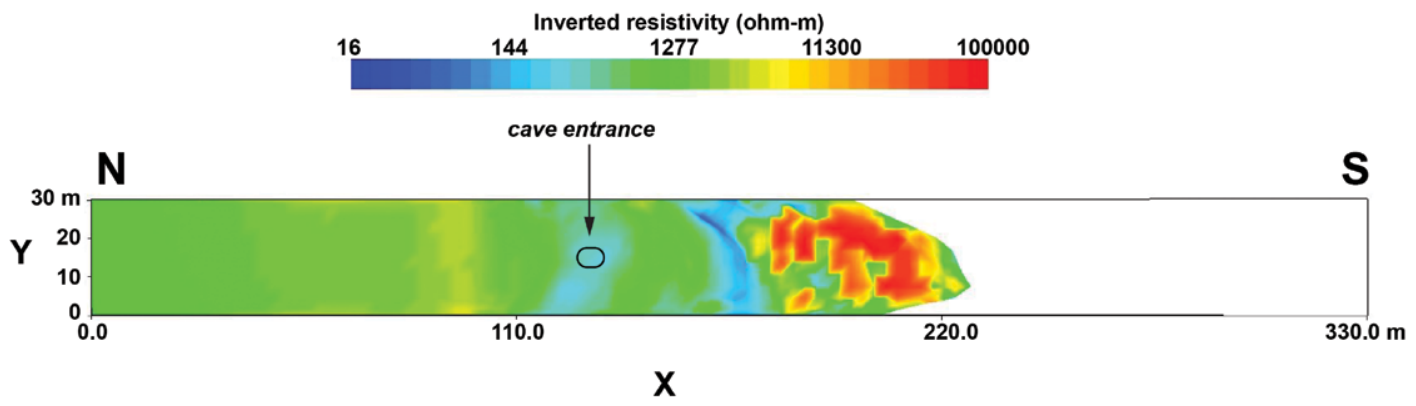

\section{Z slice: 1407 m}

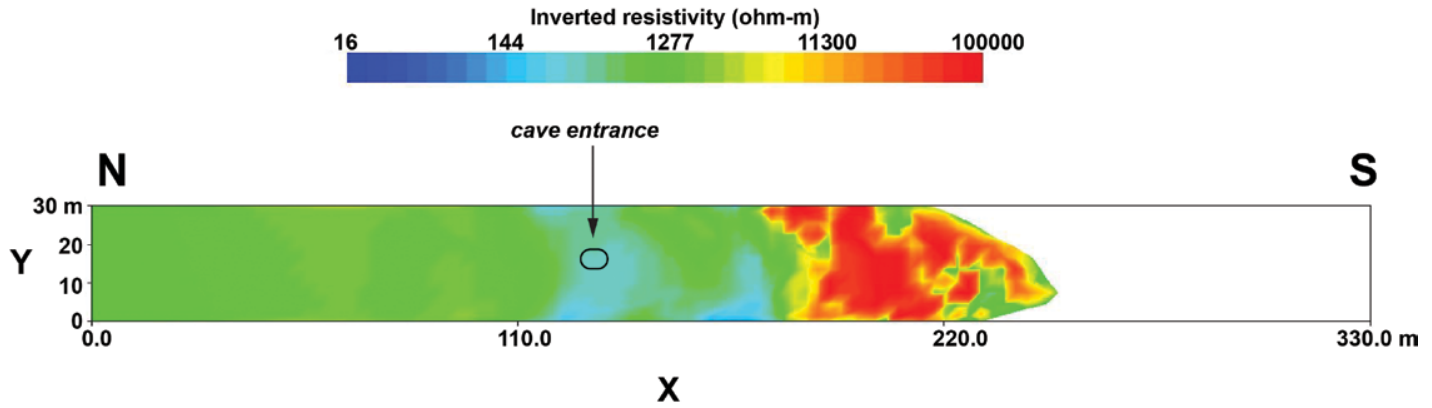

\section{Z slice: $1402 \mathrm{~m}$}

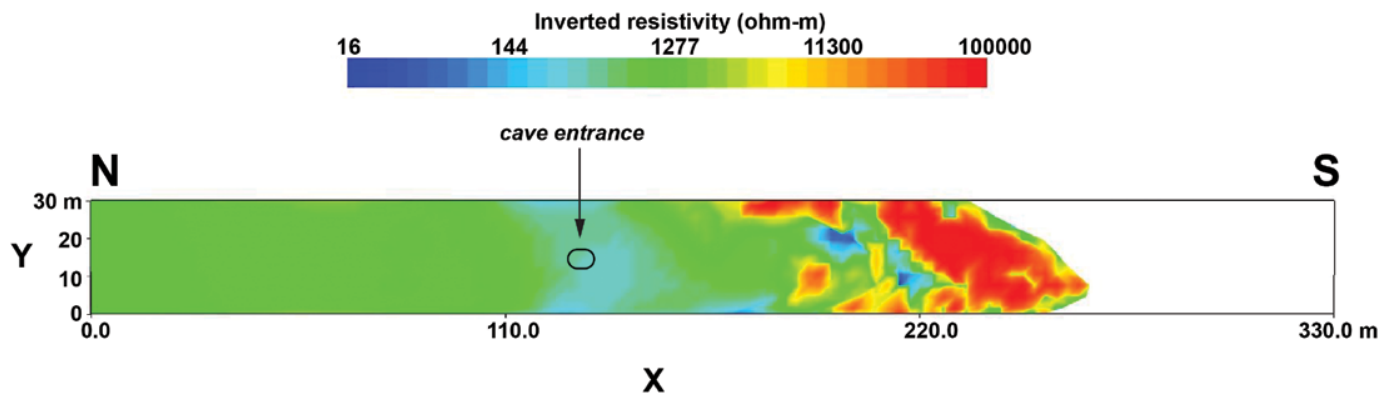

Figure 10g. 1397 m layer.
Figure 10d.1412 m layer. The absence of any zones of high resistivity reflect the fact that this slice is below the level of Manhole Cave.
Figure 10e. 1407 m layer. Zones of high resistivity on this and the two subsequent slices show the presence of a large, high-resistivity anomaly observed on 2D Lines 1 through 5.
Figure 10f. 1402 m layer.

Z slice: 1397 m

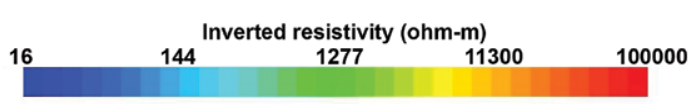

Fig. 10a shows a slice at $1427 \mathrm{~m}$ elevation, or about $4 \mathrm{~m}$ below the cave entrance. High-resistivity values at the south end of this slice reflect the air-filled void space represented by Manhole Cave. A high resistivity anomaly is also present on the $1422 \mathrm{~m}$ layer (Fig. 10b), resulting from the presence of air-filled void space near the center of the cave. These high-resistivity values begin to break up in the $1417 \mathrm{~m}$ layer, just above the cave floor (Fig. 10c), and are absent in the $1412 \mathrm{~m}$ slice (Fig. 10d), reflecting the absence of any cavities below the cave floor. However, the high-resistivity 


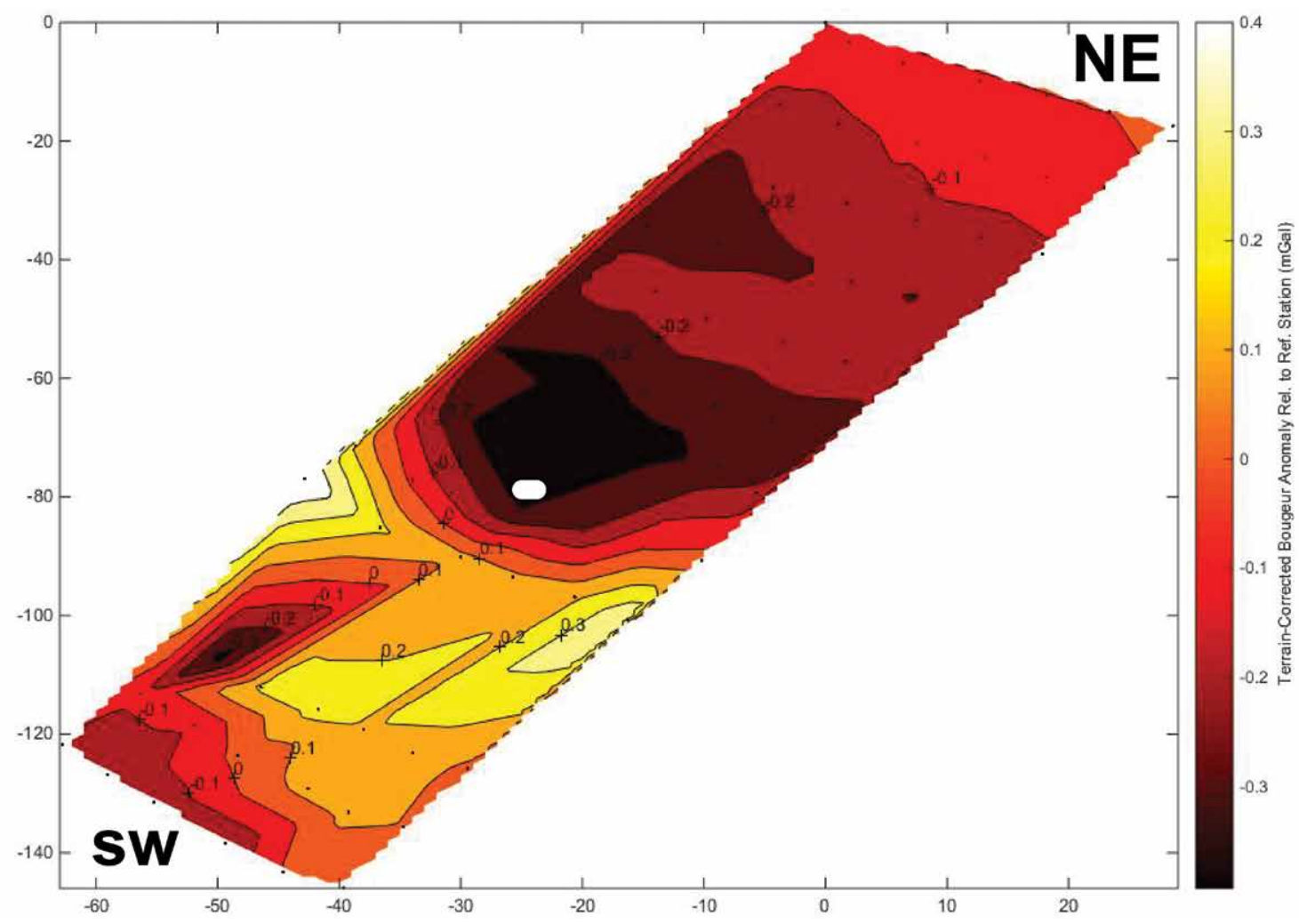

Figure 11. Terrain-corrected Bouguer gravity anomaly map. White oval shows location of cave entrance. Contour interval $=0.1 \mathrm{mg}$.

anomaly to the south of Manhole Cave is clearly indicated on the three slices at 1397, 1402, and $1407 \mathrm{~m}$ depth (Figs. $10 \mathrm{e}, 10 \mathrm{f}$, and 10g).

\section{Microgravity surveys}

Microgravity data were collected at 72 stations in the vicinity of Manhole Cave using a Scintrex CG-5 gravity meter (Fig. 7). A complete Bouguer gravity correction was applied to the data to account for the extreme topography of the survey area. Microgravity survey results clearly indicate a negative gravity anomaly in the vicinity of Manhole Cave. Another gravity low is visible south-southwest of the cave entrance (Fig. 11). The gravity data are consistent with resistivity surveys, suggesting the presence of a large cave system south of Manhole Cave. However, the more southerly gravity low is only defined by two stations. The somewhat ambiguous character of the microgravity data, in contrast with the resistivity results, may indicate the presence of a large, breakdown-filled passage, as opposed to open void space, which would produce a high electrical resistivity signal, but a less clearly-defined microgravity anomaly.

An alternative explanation for the smaller anomaly to the south is that the southern cave is deeper than Manhole Cave, and is not entirely surrounded by the gravity survey. Gravity anomalies integrate subsurface density distribution weighted by $1 / \mathrm{r}^{2}$, thus density variations at greater depths will have a smaller surface manifestation. In general, deeper subsurface anomalies have a smaller and smoother signature than shallower anomalies. Complicating the interpretation, the gravity survey does not surround the entire negative anomaly, further smoothing the image.

The absence of a gravity anomaly in the southeast corner of the gravity survey, where ER data indicate subsurface void space (Fig. 8A), may be due to inadequacies in the $10 \mathrm{~m}$ DEM-based terrain correction, which may simply not have resolved the ruggedness of the terrain. Less than ideal field conditions (steep cliffs, deep canyons, and strong winds) may have also contributed to the ambiguous gravity results.

\section{Conclusions}

Resistivity surveys conducted over Manhole Cave show a laterally-extensive, high-resistivity anomaly approximately 35-120 m south-southwest of the cave entrance. Given the geologic setting, the high-resistivity signal identified on the ER lines probably indicates the presence of a large, air-filled cavity 25 to $30 \mathrm{~m}$ below ground level. Microgravity survey results are less conclusive, but consistent with analysis of the resistivity data. The results of these geophysical surveys suggest that additional digging should eventually result in intersection with deeper cave passages southwest of Manhole Cave. 
The entrance to Manhole Cave is located less than $300 \mathrm{~m}$ north of the Carlsbad Caverns National Park boundary. Lechuguilla Cave is located within the Park, but at its closest point Lechuguilla is only $300 \mathrm{~m}$ (map distance) from BLM administered land. If a connection is ultimately established between Manhole and Lechuguilla caves, it will create a unique situation, wherein a world-class scientific resource is subject to dual management by two federal agencies with different agendas and management styles. BLM and NPS personnel have already discussed joint management of this resource, but as one BLM resource manager has observed, the devil is in the details.

\section{References}

Blakely, R.J., 1995, Potential theory in gravity and magnetic applications: New York (NY): Cambridge University Press, 441 p. https://doi. org/10.1017/CBO9780511549816.

Bretz, J.H., 1949, Carlsbad Caverns and other caves of the Guadalupe Block, New Mexico: Journal of Geology 57, no. 5, p. 447-463. https://doi. org/10.1086/625660.

Gulden, B., 2016a, USA deepest caves: National Speleological Society Geo 2. http://www.caverbob.com/usadeep.htm. [accessed February 7, 2017]

Gulden, B., 2016b, World's longest caves: National Speleological Society Geo 2. http://www.caverbob.com/wlong.htm. [accessed February 7, 2017]

Hayes, P.T., 1964, Geology of the Guadalupe Mountains, New Mexico: U.S. Geological Survey Professional Paper, p. 446.

Hill, C.A., 1987, Geology of Carlsbad Cavern and other caves in the Guadalupe Mountains, New Mexico and Texas: New Mexico Bureau of Mines and Mineral Resources Bulletin, p. 117.

Hinze, W.J., von Frese, R.R.B., and Saad, A.H., 2013, Gravity and magnetic exploration: Principles, practices, and applications: New York, NY, Cambridge University Press. https://doi.org/10.1017/CBO9780511843129.

Hiss, W.L., 1975a, Stratigraphy and ground-water hydrology of the Capitan Aquifer, southeastern New Mexico and western Texas: [Ph.D. dissertation]. Boulder, Colo.: University of Colorado, $396 \mathrm{p}$.

Hiss, W.L., 1975b, Chloride ion concentration in ground water in Permian Guadalupian rocks, southeast New Mexico and west Texas: New Mexico Bureau of Mines and Mineral Resources, Resource Map 4.

Kelley, V.C., 1971, Geology of the Pecos country, southeastern New Mexico: New Mexico Bureau of Mines and Mineral Resources, Memoir 24.

King, P.B., 1948, Geology of the southern Guadalupe Mountains, Texas. U.S.: Geological Survey Professional Paper 215.

Klimchouk, A., 2007, Hypogene speleogenesis: Hydrogeological and morphogenetic perspective: National Cave and Karst Research Institute Special Paper no. 1.

Land, L., 2003, Regional geology of the Pecos Country, in Johnson, P.S., Land, L., Price, L.G., Titus, F., eds., Water Resources of the Lower Pecos Region, New Mexico: Science, Policy, and a Look to the Future: New Mexico Bureau of Geology and Mineral Resources, 2003 New Mexico Decision Makers Guidebook, p. 9-13.

Land,.L, Veni, G., 2012, Electrical resistivity surveys of anthropogenic karst phenomena, southeastern New Mexico: New Mexico Geology 34, no. 4, p. 117-125.

Land, L., 2013, Evaporite karst in the Permian Basin region of west Texas and southeastern New Mexico: The human impact, in Land, L., Doctor, D.H., Stephenson, J.B., eds., Proceedings of the Thirteenth Multidisciplinary Conference on Sinkholes and the Engineering and Environmental Impact of Karst, Carlsbad, New Mexico: National Cave and Karst Research Institute Symposium 2. Carlsbad, NM, National Cave and Karst Research Institute, p. 113-121. https://doi.org/10.5038/9780979542275.1119.

Lange, A.L., 1992, Natural-potential survey over Big Manhole Cave, Eddy County, New Mexico: Unpublished report submitted to U.S. Bureau of Land Management, Carlsbad, New Mexico, 13 April, 1992.

Longman, I.M., 1959, Formulas for computing the tidal accelerations due to the moon and the sun: Journal of Geophysical Research 64 , p. 2351-2355. https://doi.org/10.1029/JZ064i012p02351.

McLean, J.S., 2005, Earth resistivity measurements at Big Manhole Cave: Southwest Region, National Speleological Society, Winter Technical Meeting, Carlsbad, New Mexico, December 3rd, 2005. Abstract.

Northup, D.E., Dahm, C.N., Melim, L.A., Spilde, M.N., Crossey, L.J., Lavoie, K.H., Mallory, L.M., Boston, P.J., Cunningham, K.I., and Barns, S.M., 2000, Evidence for geomicrobiological interactions in Guadalupe caves: Journal of Cave and Karst Studies, v. 62, no. 2, p. 80-90.

Palmer, A.N. and Palmer, M.V., 2000, Hydrochemical interpretation of cave patterns in the Guadalupe Mountains, New Mexico. Journal of Cave and Karst Studies, v. 62, no. 2, p. 91-108. 